\title{
Sleepwalking in Italian Operas: A Window on Popular and Scientific Knowledge on Sleep Disorders in the 19th Century
}

\author{
Michele Augusto Riva ${ }^{a, b}$ Vittorio Alessandro Sironi ${ }^{a} \quad$ Lucio Tremolizzo $^{c}$ \\ Carolina Lombardi $^{d}$ Giovanni De Vito $^{b}$ Carlo Ferrarese ${ }^{c}$ Giancarlo Cesana $^{b}$ \\ ${ }^{a}$ Research Centre on the History of Biomedical Thought, ${ }^{b}$ Research Centre of Public Health, Department of Clinical \\ and Preventive Medicine, and ' Neurology Section, Department of Neurosciences and Biomedical Technologies, \\ University of Milano-Bicocca, Monza, and d Department of Cardiology, S. Luca Hospital, IRCCS, Istituto Auxologico \\ Italiano, Department of Clinical and Preventive Medicine, University of Milano-Bicocca, Milan, Italy
}

\section{Key Words}

Sleepwalking $\cdot$ History of neurology $•$ Italian operas •

Shakespeare

\begin{abstract}
There is little knowledge on sleepwalking in ancient times even though it is a very common condition. The aim of this report is to describe the backgrounds of medical knowledge on somnambulism in the 19th century, a key period in the development of neurosciences, by analysing its representation in two famous Italian operas: La Sonnambula by Vincenzo Bellini and Macbeth by Giuseppe Verdi. The 19th-century operas may be considered as a crossing point between the popular and intellectual world because they mirror popular answers to phenomena that were still awaiting scientific explanations. Shakespeare's play Macbeth was also considered. In Shakespeare's play and in Verdi's Macbeth, sleepwalking is looked upon as a neuropsychiatric disorder, a manifestation of internal anxiety. In La Sonnambula by Bellini, this condition is considered as common disorder that anticipates scientific theories. The analysed Italian operas provide two different views on sleepwalking, probably because they are based on texts belonging to different periods. Their examination allows one to understand the gradual evolution of
\end{abstract}

theories on sleepwalking, from demoniac possession to mental disorder and sleep disease. At the same time, this analysis throws some light on the history of psychological illnesses.

Copyright $\odot 2010$ S. Karger AG, Basel

\section{Introduction}

Together with confusional arousal and sleep terrors, sleepwalking is classified as a disorder of arousal characterized by short simple behaviour or longer wandering episodes [1]. Disordered-arousal mechanisms with inability of the brain to fully awaken from slow-wave sleep are thought to lead to motor automatisms, including leaving the bed and walking [2]. Sleepwalking episodes usually occur during the first 2 or $3 \mathrm{~h}$ of sleep, when sleep stages 3 and 4 are most prevalent. Sleepwalking episodes usually begin abruptly; patients show a blank expression, indifferent to the environment, with a low level of awareness and reactivity. In the state of somnambulism, patients are confused, disoriented and unresponsive; they fail to achieve full consciousness and are extremely difficult to wake up. They move around and perform normal actions as when awake (walking, cleaning, talking and 
other activities), without awareness or memory of the episode [3]. This sleep disorder is also called somnambulism from the Latin terms 'somnus' (sleep) and 'ambulare' (to walk around) [4].

There is little knowledge on this disease in ancient times. Like several other neurological diseases (e.g. epilepsy, sleepwalking was incorrectly explained by different theories and, until the Renaissance, this disorder was ascribed to either demoniac or divine possession. Later, until the early 19th century, a sleepwalker was considered as an insane person, and this state was linked to madness and other mental disorders. Only in the last century, when sleep medicine developed, somnambulism was classified as a sleep disease belonging to the group of parasomnias [5].

Ancient myths openly related to sleepwalking are not known, but tales of demoniac/divine possession, widely diffused in all ancient populations, could give us indirect evidence of this phenomenon. Like epilepsy, somnambulism was considered as a 'sacred disease' with worrying, spectral and typically nocturnal manifestations. Afflicted persons did not remember anything, as if possessed by metaphysical forces dominating body and mind. In different countries, many ancient tales and myths told about kidnappings in the sleep by gods or evil beings: these stories might not be considered only as bugbears to scare kids at bedtime, but they could be uncorrected interpretations of episodes of sleepwalking in children. Indeed, sleepwalking is more common in childhood nowadays (at least one episode in $16 \%$ of children under 12 years old) [6], and this was possibly also true in ancient times. To a scared mother, a somnambulist son could seem to be possessed and kidnapped by evil beings. Moreover, in classic myths (e.g. Lamiae and Empusae, goddess Hecate's daughters) and in Jewish folklore (e.g. Lilim, Lilith's daughters), several female genies kidnapped and ate young men after sunset (boys are more likely to sleepwalk than girls) [7]. In the Middle Ages, most townsfolk feared that sleepwalking could be a contagious evil. Those with sleepwalkers in their families were often shunned by the community. Therefore, in many villages, this condition was considered as a curse, a plague, a mark of evil, or the punishment for some unconfessed sin.

As the 16th-century Spanish writer Antonio de Torquemada notes, the devil influences dreams which provoke sleepers 'to commit follies, i.e. sleepwalking, whereby we may lose both body and mind at once' [8]. These words show a gradual modification of the approach during the Renaissance, from demoniac possession to mental disorder/psychosomatic disease. In Russian, Polish and
Czech, for example, the word 'lunatic' refers to a sleepwalker, literally 'one who walks under the moon' or 'moonwalker'. Furthermore, this word (from the Latin term 'luna', 'moon') denotes the traditional link made in folklore between madness and the moon phases [9].

These paranormal aspects of sleepwalking derived from popular superstitions fascinated some quacks, who provided new, bizarre theories on it. The psychosomatic aspects of this disorder stimulated the studies on magnetism and hypnotic suggestion conducted by F.A. Mesmer in the 18th century and by others afterwards. At the end of the following century, several metaphysical speculations regarding this disease also persisted among physicians, but positivist ideas deprived it from every magical and psychiatric connotation, paving the way for experiments on sleep and its disorders, which led to the identification of both parasomnias and dyssomnias. The 19th century is a key period in the development of neurosciences, but aspects related to sleep disorders (and in particular sleepwalking) were not frequently studied. The aims of this analysis are to describe the backgrounds of medical knowledge on somnambulism in the Romantic Age by analysing its representation in some famous Romantic Italian operas.

\section{Methods}

Romantic Italian operas are the expression of the 19th-century atmosphere and popular beliefs. These works can give us precious information on medical knowledge of this period because they mirror popular answers to phenomena that still awaited scientific explanations. The operas were not really popular shows: the audience was mainly composed of upper-class and more educated people. For this reason, these works could be considered as a crossing point between the popular and intellectual world. The subject of sleepwalking was particularly attractive to librettists because in those days it was considered as mysterious and magical also by physicians. Nowadays, sleep disorders are also widely present in movies, television programmes, literature and comics, where the authors insert a sleep disturbance 'as a comic element, and/or to pique the curiosity of the reader or film viewer' [10].

The libretti of two successful operas with sleepwalking as subject, La Sonnambula by Vincenzo Bellini and Macbeth by Giuseppe Verdi, were analysed in the present study. These plays allow one to investigate medical and popular backgrounds of the situation in which their libretti were written. Even though Verdi's opera is more recent than Bellini's, it will be examined first because its libretto is based on a play written by Shakespeare long before the Romantic period.

Thus, the analysis of Verdi's opera together with the original play by Shakespeare may offer a more complete summary of the development of knowledge on somnambulism in the 17 th century, when the original English drama was written. 


\section{Results}

Macbeth by Giuseppe Verdi (1847)

Macbeth is an opera in four acts by Giuseppe Verdi (1913-1901) on an Italian libretto by Francesco Maria Piave, based on the homonymous play by Shakespeare. Piave's text was based on a prose translation by Carlo Rusconi that had been published in Turin in 1838. The first performance of the opera was at the Teatro della Pergola in Florence, on March 14th, 1847 [11].

The plot of the Shakespearian tragedy is very famous. In the 11th century Macbeth, Thane of Glamis, obeying a prophecy told by three witches, kills his cousin Duncan, King of Scotland, and takes his place. His wife, Lady Macbeth, helps him, incriminating the royal sleeping guards by smearing them with Duncan's blood. But the new tyranny is short. Malcolm, King Duncan's son, and the English army, march against Macbeth and liberate the kingdom. After receiving the news of the repenting Queen's suicide with indifference, the tyrant is pursued and killed by Macduff, Thane of Fife. The opera ends with a hymn to victory sung by bards, soldiers and Scottish women.

The scene of sleepwalking occurs in Act Four of Verdi's opera. In the castle, a doctor and a gentlewoman, attendant on Lady Macbeth, observe the Queen as she walks and talks in her sleep, wringing her hands and attempting to clean them from blood ('Una macchia', 'A spot', Scene Four). Both are frightened ('Ridirlo non debbo a uom che viva', 'I must not repeat to a man who lives'; 'Oh terror! ..., 'Oh terror! ...') and invoke the Lord's mercy on Macbeth's wife because only God can save her ('Ah, di lei pietà, Signor!', 'Lord, have mercy on her') [11].

Piave's libretto, although following Shakespeare's play quite closely, does not provide the same information on sleepwalking [12]. In the English play (Act Five, Scene One), the description of the state of somnambulism is more complete ('... I have seen / her rise from her bed, throw her night-gown upon / her, unlock her closet, take forth paper, fold it, / write upon't, read it, afterwards seal it, and again / return to bed; yet all this while in a most fast sleep'; 'You see, her eyes are open / Ay, but their sense are shut'), like the doctor's comments ('A great perturbation in nature, to receive at once / the benefit of sleep, and do the effects of / watching! ...'). The Shakespearian 'Doctor of Physic' admits to be unable to cure the Queen because she does not suffer from an organic disease ('This disease is beyond my practise: yet I have known / those which have walked in their sleep who have died / holily in their beds'; 'More needs she the divine than the physician'), but he gives generic advice ('... Look after her /
Remove from her the means of all annoyance / And still keep eyes upon her'). The perceived aetiology of somnambulism seems quite evident: it is considered as a sort of a mental disease, possibly a post-traumatic disorder ('... heaven knows what she has known'; 'What a sigh is there! The heart is sorely charged'; 'Foul whisperings are abroad: unnatural deeds / Do breed unnatural troubles: infected minds / To their deaf pillows will discharge their secrets'). In the original play the characters are frightened by the scene as well ('My mind she has mated, and amazed my sight / I think, but dare not speak') [13].

Verdi's music adds a new element to the scene of Lady Macbeth sleepwalking: the Queen sings low, joining to the musical accompaniment, creating a suggestive and mystic atmosphere. When the composer thought of the scene of somnambulism, the expression of madness caused by a sense of guilt, his opinion was that the voice of the Queen should be ungraceful and evil. For this reason, Verdi, in the first performance of the opera (1847), refused the famous singer Tadolini because her voice was too beautiful and angelic [11].

\section{La Sonnambula by Vincenzo Bellini (1831)}

La Sonnambula (The Sleepwalker) is an opera semiseria (a work containing elements of comedy but also of pathos) written in two acts by the Sicilian composer Vincenzo Bellini (1801-1835) on an Italian libretto by Felice Romani. Based on a comédie-vaudeville by the French dramatist Eugène Scribe (La somnambule, 1819), the first performance of the opera was at the Teatro Carcano in Milan, on March 6th, 1831 [14]. It is regarded as Bellini's masterpiece, together with I Puritani and Norma.

In this play, set in a Swiss village, Amina is betrothed to Elvino and the villagers organize the wedding celebrations. A stranger arrives, asking the way to the castle, and lodges at the inn. As darkness approaches, the villagers warn the foreigner that it is time to be indoors to avoid the village phantom, but he is not superstitious and assures them that they will soon be free of the apparition. The stranger is recognized as Rodolfo, the long-lost son of the previous count and the village prepares a formal welcome to him. During the night, Amina, walking in her sleep, enters the room of Rodolfo, who realizes that her nocturnal wanderings have given rise to the story of the village phantom. At the same time, villagers enter the inn to welcome their new lord and find Amina sleeping on Rodolfo's sofa. Elvino, believing Amina faithless, rejects her and decides to marry another woman. They are about to go to the church when Rodolfo tries to explain that Amina is innocent because she had not come to his 
room awake, she is a somnambulist, a sleepwalker. The proof is dramatically produced when Amina is seen walking in her sleep across the high, dangerously unstable mill bridge. Now Elvino can marry Amina.

In this opera, the sleepwalker Amina is considered as a phantom by the villagers ('l'ora s'avvicina in cui si mostra / Il tremendo fantasma', 'It's time when the terrible phantom appears') but Rodolfo does not believe in ghosts and makes fun of folk ('Follie ... Credulità', 'Foolishness ... Credulity'). The somnambulism scenes are two. In the first act, Amina enters Rodolfo's room. The count realizes Amina's state of somnambulism ('Dorme/ E' sonnambula', 'She sleeps / She is a sleepwalker') and he is afraid of awaking her ('Ah! Non si dèsti', 'She mustn't be awaked'). In the second act, Rodolfo explains the sleepwalking state to Elvino ('V'han certuni che dormendo / Vanno intorno come dèsti, / Favellando, rispondendo / Come vengono richiesti, / E chiamati son sonnambuli / Dall'andar e dal dormir', 'Some people while they are sleeping / walk around like awake / talking and replying / to every question / They are called sleepwalkers / because they sleep and walk around'), but nobody believes him ('A tai fole non crediamo', 'We don't believe these fairy-tales'). Suddenly, the sleepwalker enters the stage. Rodolfo warns that to wake her would be fatal ('Silenzio: un sol passo / Un sol grido l'uccide', 'Silence! One movement / one cry will kill her'), so all watch as she laments over her betrothal and at Elvino's rejection in the famous aria 'Ah! Non credea mirarti ...' ('Ah! I don't think to see you ...'). Only her lover's repenting voice rouses her from her deep state of somnambulism [14]. The somnambulist aria is very renowned among melodrama fans because it is difficult to sing and to play for every soprano. The notes of its incipit were written on Bellini's gravestone in the Duomo of Catania because of the beauty of the aria.

\section{Discussion}

\section{Macbeth: Sleepwalking as a Neuropsychiatric Disorder}

Shakespeare's play, more than Verdi's opera, which is based on it, accurately describes medical knowledge under King James I, in the 17th century. Many scholars (e.g. Braunmuller) believe that Macbeth was most likely written between 1603 and 1606 [13]. They suggest the play is unlikely to be earlier than 1603 as it was apparently written to celebrate King James's ancestors and the Stuarts' accession to the throne in 1603 (James believed himself to be descended from Banquo, Macbeth's friend). The King was very interested in occult sciences: he wrote literary works, such as Daemonologie (1597) and Basilikon Doron (1599), and broadened the Elizabethan Witchcraft Act (1604) [8]. This Jacobean atmosphere influenced Shakespeare's works as well as the theories of physicians.

James demonstrated an interest in sleepwalking because he and his mother (Mary, Queen of Scots) suffered from fits of unconsciousness and lack of sleep, but the relationship between mind and body attracted physicians (and writers) before James's reign. Indeed, the first description of a psychosomatic disease appears in A Treatise of Melancholy' by the English doctor Timothy Bright (1551-1615) and the first link between these disorders and somnambulism was presented in De Miraculis Occultis Naturae by Lemnius Levinus (1505-1568). In his treatise, the Dutch physician provided some suggestions to the readers: 'not to call night-walkers by their proper name [...] wherefore you must let them go as they will, and retire again at pleasure'. Some books on sleep and its disorders widely circulated in Jacobean England, like Somniorum Synesiorium by Gerolamo Cardano (1562), De Natura Iuxta Propria Principia by Bernardino Telesio (1565), and De Somno by Johannes Argentarius (1556). In these works, which influenced medical thought and Shakespeare's play, sleepwalking was defined as a 'serious disorder', a 'form of melancholy', and 'a great agitation of the brain'. During James's reign, some members of the College of Physicians (such as Sir William Paddy) and Royal Archiaters had these books in their library [8].

The English play and Piave's libretto both reflect these ideas: sleepwalkers should not be awakened; somnambulism is a neuropsychiatric disorder and a manifestation of internal anxiety or, in religious terms, of sin.

\section{The Romantic Approaches to Somnambulism}

La Sonnambula by Bellini offers a true picture of the 19th century atmosphere. Count Rodolfo is the symbol of Illuminist and scientific ideas against popular superstitions. Somnambulism is neither a supernatural manifestation, nor a demoniac possession, nor a punishment for a sin, but it is simply a common disorder. Rodolfo does not regard it as a disease yet, because sleepwalking was not considered as such by contemporary physicians.

In Italy, in that period, the works of the poet Giuseppe Gioachino Belli's (1791-1863) and popular magnetism 
are representative for two different Romantic approaches to somnambulism. In 1833, Belli, who was famous for his plays composed in Romanesco (the dialect of Rome), wrote in the sonnet 'La Sonnampola' (The sleepwalking woman): 'Questa è un'ammalattia, che a chi glie pija / Lo fa discorre e nun je rope er zonno: / E ce so' tanti che, dormendo, pònno / Fà ogni faccenna e camminà le mija' ('This is a disease which makes an afflicted person / talk without waking up: / and, while sleeping, many people can / do every thing and walk miles') [15]. In contrast to Bellini's libretto, in Belli's contemporary sonnet, somnambulism was called a disease, showing that illuminist ideas on this disorder triumphed over superstitions. The second approach is represented by 'somnambular magnetism', which was successful in Italy at the end of the 19th century and at the beginning of the last century [16]. In different 'magnetic cabinets', which had been opened in all main cities of the country, from Turin to Naples, a supposed sleepwalker and her magnetist maintained that they could foretell the future and gave consultations on diseases. Sleepwalking was not anymore the subject of a play, but had become itself a show. These practices were looked upon as superstitions by the Catholic church (defined in Latin as 'parva ac haeraticalis superstitio', 'light and heretical superstition'), and afterwards pretenders were tried for fraud. Nevertheless, 'somnambular magnetism' vanished from Italy only in the first half of the last century, where it had represented a form of popular medicine almost for 100 years.

This relationship between sleepwalking and magnetism was also found in other previous literary and historical descriptions. In the first half of the 19th century, baron Karl Ludwig von Reichenbach (1788-1869), member of the Prussian Academy of Sciences, made extensive studies on sleepwalkers, and used some discoveries to formulate his theory of the Odic force, based on mesmeric animal magnetism [17]. Indeed, in the popular opinion, somnambulism always followed the appearance of specific lunar phases, reaching maximum expression at full moon (it was linked to werewolf legends). Like animal magnetism, this 'lunar attraction' was a manifestation of a more fundamental natural force. Baron von Reichenbach named this vital principle 'Odic force' (from Odin, mythological Nordic god), which pervades and connects all living things. The theories of Armand M.J. de Chastenet, Marquis de Puységur (1751-1825) were very similar. Even this French aristocrat learned about mesmerism, studied 'artificial sleepwalking' for many years (at present known as 'hypnosis') and noted the similarity between this sleeping trance and somnambulism [18]. He based both phenomena on the vital principle, similar to the modern idea of subconscience, which would be developed through researches on hypnotism by J.M. Charcot and his fellow, S. Freud. These metaphysical theories persisted in some Gothic novels in the Northern European literature (e.g. 'artificial sleepwalking' in Dracula by Bram Stoker, 1897) [19].

\section{Conclusion}

In conclusion, the two analysed Italian operas provide two different views on sleepwalking even though they are contemporaneous. Indeed, their libretti are based on texts of different period (Shakespeare and Scribe), and, for this reason, they present dissimilar ideas about somnambulism. The analyses conducted on the Shakespearian play and on La Sonnambula allow one to understand the gradual evolution of theories about sleepwalking from demoniac possession to mental disorder and sleep disease. Therefore, their examination throws light on the history of psychological illnesses. Undeniably, Jacobean investigations on somnambulism can be considered as the first acknowledgment of psychosomatic disorders whereas 19 th century research was very important for the development of hypnosis and Freud's theories on subconscience.

These operas share something: both sleepwalking episodes occur in adults. In the adult population, the differential diagnosis of paroxysmal motor events during sleep represents an arduous issue. From the analysis of the descriptions of Lady Macbeth and Amina, we can derive some important clinical information. The sleep disease which affects Amina is probably an Non-Rapid Eye Movement (NREM) parasomnia or an arousal disorder (sleepwalking). This disorder typically occurs during the deepest stage of NREM sleep (slow-wave sleep), usually within 1-2 h after sleep onset; the patients may exhibit a wide variety of non-stereotypical behaviours that include short simple behaviour or longer wandering episodes, with the completion of complex but purposeless tasks and some ability to interact with their environment. Typically, these patients have no memory of the events, but they may remember fragments, flashes, or vague impressions of the events. During sleepwalking, the patient may calmly walk around, may appear downstairs or may be found standing on the landing or elsewhere in the house, looking vague with eyes open. Another element of suspicion for NREM parasomnia is that Amina is a young woman. 
The diagnosis in Lady Macbeth is more complex; in fact, she presents some characteristics of NREM parasomnia (as Amina) as well as elements of REM parasomnia, such as REM behaviour disorder (RBD): adulthood, motor behaviour potentially violent. RBD is characterized by a history of dream-enacting and is often associated with dream recall. The patients most often arise in the second half of the night with sudden paroxysmal simple or massive motor activities. Episodes of RBD are characterized by more or less purposeful gestures enacting attack or defence reactions, sometimes associated with emotional expressions of joy, laughter, sorrow or cries. Speech may seem different from the usual speech, transformed. During the episode, patients may manifest behaviours completely different from those that characterize their waking state, sometimes with involuntary injurious components. However, in REM sleep behaviour disorder, the normal muscle 'atonia' of REM sleep is disrupted and patients are able to 'act out' their dreams with characteristic histories of dream-enacting, often associated with dream recall [20]. In Lady Macbeth's description, this element is not reported, but in some persons afflicted with RBD, behaviour may be similar to that observed in sleepwalking and some patients have an overlap syndrome with elements of sleepwalking and REM sleep behaviour disorders [21].

At last, in both operas there is the scare of waking up the sleepwalkers because they could die. Nowadays, this fear remains in the public opinion because movies, comics and literature suggest this theory even though it has been scientifically refuted. For this reason, we may conclude with a reflection on the power of the media to entertain superstitions and folk beliefs in our society, exactly as some operas did in the 19th century.

\section{References}

1 American Academy of Sleep Medicine: International Classification of Sleep Disorders, ed 2. Diagnostic and Coding Manual. Westchester, American Academy of Sleep Medicine, 2005.

$\checkmark 2$ Broughton RJ: Sleep disorders: disorders of arousal? Enuresis, somnambulism, and nightmares occur in confusional states of arousal, not in 'dreaming sleep'. Science 1968;159:1070-1078.

3 Bassetti CL, Bischof M, Valko P: Dreaming: a neurological view. Schweiz Arch Neurol Psychiatr 2005;156:399-414.

4 Ferrio L: Terminologia Medica. Torino, Unione Tipografico-editrice Torinese, 1931.

5 The International Classification of Sleep Disorders, rev: Diagnostic and Coding Manual. Rochester, American Sleep Disorders Association, 1997.

6 Klackenberg G: Somnambulism in childhood: prevalence, course, and behavioural correlations. Acta Pediatr Scand 1982;71: 495-499.
7 Petit D, Touchette E, Tremblay RE, Boivin M, Montplaisir J: Dyssomnias and parasomnias in early childhood. Pediatrics 2007;119: 1016-1025.

8 Pady DS: The medico-psychological interests of King James I. Clio Med 1984;19:2231.

>9 Raison CL, Klein HM, Steckler M: The moon and madness reconsidered. J Affect Disord 1999;53:99-106.

10 Iranzo A, Schenck CH, Fonte J: REM sleep behavior disorder and other sleep disturbances in Disney animated films. Sleep Med 2007;8:531-536.

11 Piave FM: Macbeth: dall'omonima tragedia di William Shakespeare. Introduzione e note di Emanuela Scuccato. Collogna ai Colli, La libreria di Demetra, 1996.

12 Furman Y, Wolf SM, Rosenfeld DS: Shakespeare and sleep disorders. Neurology 1997; 49:1171-1172.

13 Shakespeare W: Macbeth. A cura di Nemi D’Agostino. Milano, Garzanti, 2007.

14 Romani F: La Sonnambula: melodramma in due atti. Testi a cura di Eduardo Rescigno. Milano, Ricordi, 1990.

15 Teodonio M: Belli, tutti i sonetti romaneschi. Roma, Newton, 1998.
16 Gallini C: La sonnambula indovina. Il magnetismo popolare in Italia nell'Ottocento. Ric Folklor 1983;8:43-56.

17 Von Reichenbach K: Physikalisch-physiologische Untersuchungen über die Dynamide des Magnetismus, der Elektrizität, der Wärme, des Lichtes, der Krystallisation, des Chemismus in ihren Beziehungen zur Lebenskraft. Braunschweig, Vieweg, 1850.

18 Chastenet de Puységur AMJ: Recherches, expériences et observations physiologiques sur l'homme dans l'état de somnambulisme naturel, et dans le somnambulisme provoqué par l'acte magnétique. Paris, Dentu, 1811.

19 Stiles A: Cerebral automatism, the brain, and the soul in Bram Stoker's Dracula. J Hist Neurosci 2006;15:131-152.

$\checkmark 20$ Avidan AY: Parasomnias and movement disorders of sleep. Semin Neurol 2009;29:372392.

21 Schenck CH, Boyd JL, Mahowald MW: A parasomnia overlap disorder involving sleepwalking, sleep terrors, and REM sleep behaviour disorder in 33 polysomnographically confirmed cases. Sleep 1997;20: 972-981. 